\title{
ROZWÓJ ENERGETYKI WIATROWEJ W CHINACH
}

Energetyka wiatrowa przechodzi okres dynamicznego rozwoju. W ciagu ostatniej dekady łączna moc zainstalowanych na świecie turbin wiatrowych wzrosła pięciokrotnie (ze 115,4 GW w 2008 r. do 564,3 GW w 2018 r.), a produkcja energii elektrycznej w elektrowniach wiatrowych wzrosła z 220,6 TWh w 2008 r. do 1270,0 TWh w 2018 r. $^{1}$ Od roku 2010 o 21,7\% spadła cena montowanych turbin wiatrowych - z 1913 USD/kW do 1497 USD/kW w 2018 r. Równocześnie wzrosły wskaźniki wykorzystania mocy (capacity factor) z 27\% w 2010 r. do $34 \%$ w 2018 r. Dzięki temu uśredniony koszt jednostkowy wytwarzania energii elektrycznej (Levelized Cost of Electricity - LCOE) w turbinach wiatrowych zlokalizowanych na lądzie (onshore) zmniejszył się z 0,08 USD/kWh w 2010 r. do 0,06 USD/kWh w 2018 r. $^{2}$ Warto też zwrócić uwagę na niską emisję gazów cieplarnianych związana z wytworzeniem energii elektrycznej w turbinach wiatrowych - około 8-20 g na $\mathrm{kWh}$, co stanowi 1-2\% emisji wytwarzanych w elektrowniach weglowych ${ }^{3}$.

Od kilku lat wiodącą rolę w energetyce wiatrowej odgrywają Chiny, ale jeszcze w 2003 r. łączna moc zainstalowanych w Chinach turbin wiatrowych wynosiła tylko $547 \mathrm{MW}$, co stanowiło 1,4\% światowych mocy elektrowni wiatrowych. W tym czasie Niemcy będące w tym zakresie liderem dysponowały mocą elektrowni wiatrowych rzędu 14381 MW. W USA łączna moc elektrowni wiatrowych wynosiła 5995 MW, a w Hiszpanii 5945 MW. W 2018 r., tj. 15 lat później Chiny stały się już zdecydowanym liderem energetyki wiatrowej z łączną moca zainstalowanych turbin wiatrowych na poziomie $184696 \mathrm{MW}$, co stanowiło 32,7\% światowych mocy elektrowni wiatrowych ${ }^{4}$.

Jak to się stało, że kraj, który jeszcze niedawno dzielił ogromny dystans do światowych liderów energetyki wiatrowej i importował technologię produkcji turbin wiatrowych, zwiększył kilkaset razy moc działających turbin wiatrowych, zdecydowanie wyprzedzając inne państwa $\mathrm{w}$ tej dziedzinie? $\mathrm{Na}$ to pytanie odpowiada niniejszy artykuł, zawierający przegląd i podsumowanie literatury przedmiotu w kontekście

1 BP Statistical Review of World Energy, 2019.

2 IRENA [International Renewable Energy Agency], Renewable Power Generation Costs in 2018, Abu Dhabi 2019.

3 Y. Zhou Y., M. Pan, F. Urban, Comparing the International Knowledge Flow of China's Wind and Solar Photovoltaic (PV) Industries: Patent Analysis and Implications for Sustainable Development, „Sustainability" 2018, 10, 1883, s. 1-34.

4 BP Statistical Review of World Energy, 2019. 
najnowszych danych statystycznych. Jego głównym celem jest opisanie czynników, które zadecydowały o rozwoju energetyki wiatrowej w Chinach.

W opracowaniu postawiono trzy hipotezy badawcze. Po pierwsze, osiagnięcie tak wielkiej skali produkcji oraz wysokiego tempa rozwoju energetyki wiatrowej w Chinach wymagało zbudowania całego ekosystemu biznesowego. Po drugie, rozwój energetyki wiatrowej w Chinach nie byłby możliwy bez zapewnienia szerokiego strumienia finansowania. Po trzecie, chiński ekosystem energetyki wiatrowej nie jest nastawiony tylko na przechwytywanie wartości (value capture) związane z programami finansowymi, ale także na tworzenie wartości (value creation) w ramach działalności innowacyjnej.

Do weryfikacji hipotez zastosowano metodę opisowa, analizę porównawczą bazującą na danych wtórnych oraz studium przypadku. Pewne novum stanowi zastosowanie do analizy polityki energetycznej koncepcji inżynierii ekosystemów biznesowych, a także dwóch autorskich narzędzi: testu zaangażowania kapitału narodowego i testu innowacyjności przeprowadzonego dla chińskiego ekosystemu energetyki wiatrowej.

Koncepcję ekosystemów biznesowych (business ecosystem) wprowadził do literatury ekonomicznej James Moore w latach 90. XX wieku ${ }^{5}$. W biznesie ekosystem oznacza społeczność przedsiębiorstw i ich pracowników, dostawców, klientów, instytucji finansujących, ośrodków naukowych, różnych innych interesariuszy oraz ich wzajemne powiązania. W przypadku energetyki wiatrowej w Chinach mamy do czynienia z inżynierią budowanego od podstaw ekosystemu biznesowego, w myśl którego państwo wyznacza cele, określa odpowiednie środki finansowe i dysponuje nimi, tworzy mechanizmy wsparcia podmiotów nie tylko kontrolowanych przez rząd, ale także podmiotów prywatnych. W niniejszym opracowaniu przyjęto, że w Chinach ekosystem biznesowy w energetyce wiatrowej (rys. 1) nie powstał w sposób spontaniczny, w wyniku działania niewidzialnej ręki rynku, lecz jest wynikiem świadomej polityki gospodarczej. Kluczowe elementy tego ekosystemu, a także odbywające się w nim podstawowe przepływy zasobów oraz pieniędzy zostały wcześniej starannie zaprojektowane.

Test zaangażowania kapitału narodowego pozwala ocenić efektywność tej polityki z punktu widzenia funkcjonowania i wyników podmiotów krajowych. Kapitał narodowy jest definiowany jako bogactwo ucieleśnione w przedstawicielach danego narodu (kapitał ludzki), w majątku rzeczowym i finansowym, jaki zgromadzili, w terytorium, które zajmują, w wodach terytorialnych, które kontroluja, w zasobach, które znajdują się pod powierzchnią ziemi i na niej, a także w kulturze, która spaja i wzmacnia wspólnotę narodową oraz przyczynia się do rozwoju gospodarczego.

5 J. Moore, Predators and prey: A new ecology of competition, „Harvard Business Review”, May-June 1993, s. $75-86$. 


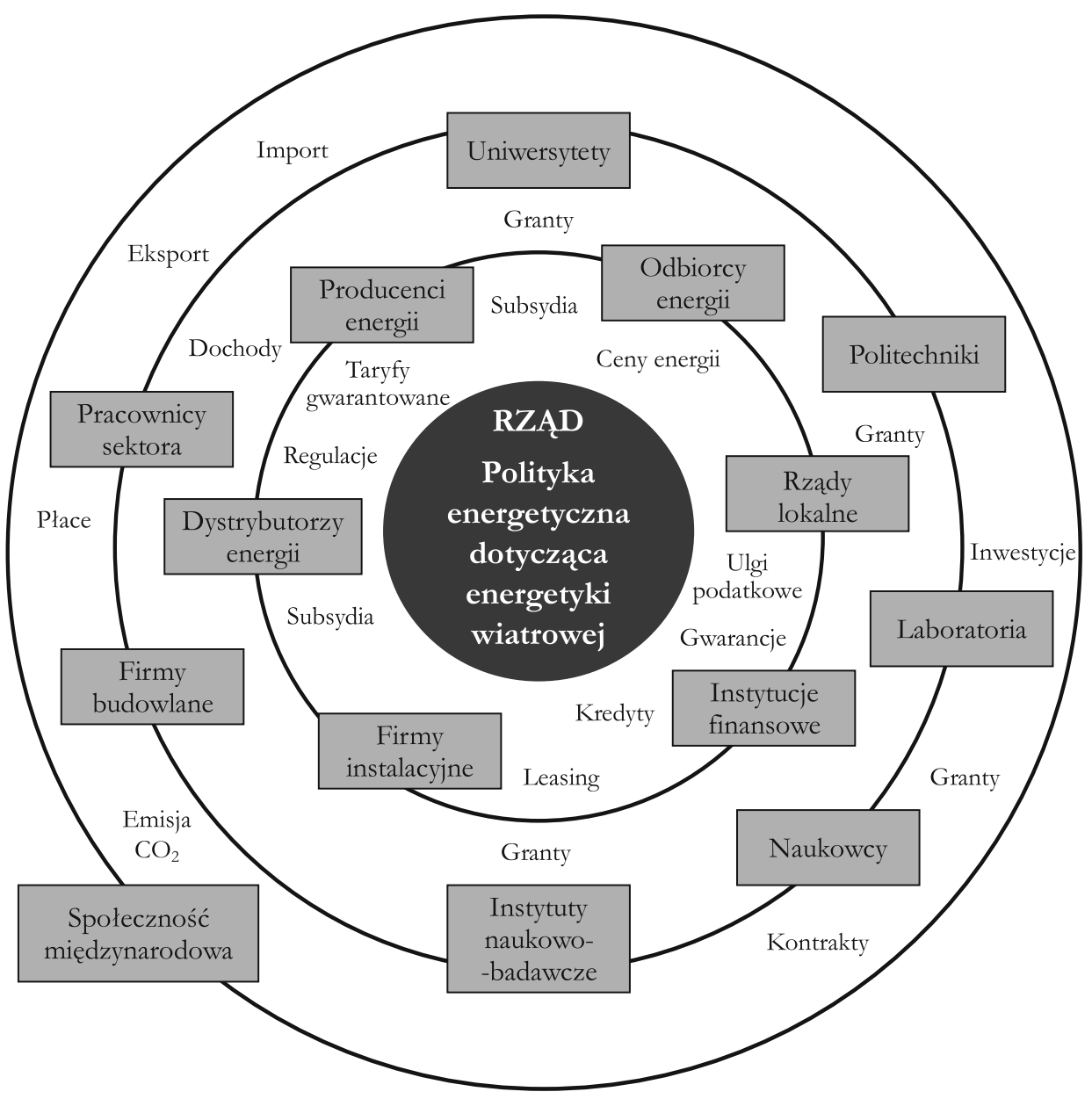

Rys. 1. Ekosystem biznesowy w chińskiej energetyce wiatrowej

Źródło: Opracowanie własne.

W teście wyróżniono trzy oceny efektów polityki gospodarczej wobec nowych sektorów: niska ocena - w przypadku, gdy udział podmiotów krajowych w procesach gospodarczych jest niewielki, tj. technologie i produkty sa importowane, a podmioty krajowe tylko uczestniczą w ich dystrybucji; średnia ocena - gdy podmioty krajowe uczestniczą nie tylko w dystrybucji, ale też w procesach wytwarzania, zdobywają doświadczenie i wiedzę w zakresie know-how, są w stanie opanować znaczną część procesów technologicznych, wysoka ocena - gdy podmioty krajowe tworzą cały łańcuch wartości w sektorze, od projektowania i wprowadzania nowych produktów/technologii, poprzez ich sprzedaż na rynku krajowym, aż do eksportu 
technologii i produktów na rynki zagraniczne i zdobywanie coraz większego udziału na tych rynkach.

Test innowacyjności ekosystemu biznesowego służy do oceny zakresu i stopnia zmian w technologiach, produktach, organizacji i funkcjonowaniu firm na rynku. Zgodnie z Oslo Manual, międzynarodowym podręcznikiem metodologicznym z dziedziny badań statystycznych innowacji, pojęcie innowacji jest bardzo szerokie „innowacja jest to wdrożenie nowego lub istotnie ulepszonego produktu (wyrobu lub usługi), nowego lub istotnie ulepszonego procesu, nowej metody marketingu lub nowej metody organizacji w zakresie praktyk biznesowych, organizacji miejsca pracy bądź relacji ze środowiskiem”. Najnowsza, czwarta edycja Oslo Manual 2018 definiuje pojęcie innowacji biznesowej jako „nowy lub ulepszony produkt lub proces biznesowy, który znacznie różni się od poprzednich produktów lub procesów biznesowych firmy i który został wprowadzony na rynek lub do własnego użytku przez firmę"’.

W teście wyróżnione zostały też trzy oceny poziomu innowacyjności ekosystemu biznesowego: niska ocena - w przypadku, gdy zmiany w technologiach, produktach, organizacji i relacjach rynkowych sa śladowe lub ich w ogóle nie ma; średnia ocena - gdy wprowadzane są tzw. innowacje miękkie (soft innovation), czyli pojawiaja się rozwiązania technologiczne, produktowe czy organizacyjne nowe dla firm (new to the company), ale nie dla całego rynku; wysoka ocena - gdy wprowadzane sa tzw. innowacje twarde (hard innovation), tj. chronione patentami nowe technologie i produkty, będące nowością dla całego rynku globalnego (new to the market).

Polityka energetyczna Chin w zakresie energetyki wiatrowej wzbudza uzasadnione zainteresowanie naukowców z całego świata. Kraj ten jest obecnie światowym liderem, jeśli chodzi o zainstalowaną moc turbin wiatrowych oraz produkcję energii elektrycznej w elektrowniach wiatrowych. Problem ten jest coraz częściej i szerzej podejmowany w literaturze. Do najczęściej podejmowanych zagadnień należy chińska polityka energetyczna bazująca na odnawialnych źródłach energii (OZE), takich jak wiatr ${ }^{8}$. W literaturze znajdziemy również opis systemu wspar-

${ }^{6}$ OECD \& European Communities, Podrecznik Oslo. Zasady gromadzenia i interpretacji danych dotyczacych innowacji, wyd. 3, Warszawa 2005.

7 OECD \& European Union, Oslo Manual 2018. Guidelines For Collecting, Reporting And Using Data On Innovation, $4^{\text {th }}$ ed., Paris/Eurostat, Luxembourg 2018.

$8 \mathrm{Na}$ ten temat zob. m.in.: J. Li, X. Zhuang, The Analysis of China's New and Renewable Energy Policies and Future Trend, „China Energy” 2001, vol. 4, s. 5-9; F. Wang, H. Yin, S. Li, China's renewable energy policy: Commitments and challenges, „Energy Policy” 2010, vol. 38, Issue 4, s. 1872-1878; L. Price, M. Levine, N. Zhou, D. Fridley, N. Aden, H. Lu, M. McNeil, N. Zheng, Y. Qin, P. Yowargana, Assessment of China's Energy-Saving and 38 Emission-Reduction Accomplishments and Opportunities During the 11 th Five Year Plan, „Energy Policy” 2011, vol. 39, Issue 4, s. 2165-2178; G. Xinyua, J. Boc, L. Bina, Y. Kaia, Study on Renewable Energy Development and Policy in China, „Energy Procedia” 2011, vol. 5, s. 1284-1290; Y. He, Y. Hu, Y. Pang, H. Tian, R. Wu, A Regulatory Policy to Promote Renewable Energy Consumption in China: Review and Future Evolutionary Path, „Renewable Energy” 2016, 
cia w Chinach energetyki wiatrowej ${ }^{9}$. Szczegółowej analizie poddany został też rozwój energetyki wiatrowej w Chinach, m.in. pod kątem innowacji i działalności z zakresu R\&D ${ }^{10}$. Tematyka energetyki wiatrowej pojawia się też w raportach różnych instytucji i organizacji ${ }^{11}$. W polskiej literaturze szczegółowy opis rozwoju energetyki wiatrowej w Chinach można znaleźć m.in. w dwóch monografiach Łukasza Gacka ${ }^{12}$.

W artykule podjęto następujące zagadnienia: rolę sektora energetycznego w gospodarce Chin, historię budowy innowacyjnego ekosystemu biznesowego w energetyce wiatrowej w Chinach, funkcjonowanie ekosystemu biznesowego w energetyce wiatrowej w Chinach w latach 2003-2018.

\section{Rola sektora energetycznego w gospodarce Chin}

Chiny notowały w ostatnich 15 latach wyjątkowo wysokie tempo wzrostu gospodarczego, przekraczające w latach 2003-2010 nawet 10\% w skali roku (tab. 1). PKB

vol. 89, s. 695-705; J. Kejun, J. Woetzel, How China is leading the renewable energy revolution, World Economic Forum, 29.08.2017, https://www.weforum.org/agenda/2017/08/how-china-is-leading-the-renewable-energy-revolution (dostęp: 10.12.2019); J. Liu, China's renewable energy law and policy: A critical review, „Renewable and Sustainable Energy Reviews” 2019, vol. 99, s. 212-219.

9 Na ten temat m.in.: J. Li, X. Zhuang, The Analysis..., s. 5-9; J. Lewis, R. Wiser, Fostering a renewable energy technology industry: An international comparison of wind industry policy support mechanisms, „Energy Policy” 2007, vol. 35, Issue 3, s. 1844-1857; L. Butler, K. Neuho, Comparison of feed-in tariffs, quota and auction mechanisms to support wind power development, „Renewable Energy” 2008, vol. 33, Issue 8; B. Shen, J. Wang, M. Li, L. Priced, L. Zenge, China's Approaches to Financing Sustainable Development: Policies, Practices, and Issues, Berkeley Lab. 2012; Z. Ming, L. Ximei, L. Na, $\mathrm{X}$. Song, Overall review of renewable energy tariff policy in China: Evolution, implementation, problems and countermeasures, „Renewable and Sustainable Energy Reviews” 2013, vol. 25, s. 260-271; F. Wang, H. Yin, S. Li, China's renewable energy policy: Commitments and challenges, „Energy Policy” 2010, vol. 38, s. 1872-1878; J. Nahm, Renewable futures and industrial legacies: Wind and solar sectors in China, Germany, and the United States, „Business and Politics” 2017, vol. 19, Issue 1, s. 68-106; Y. Liang, B. Yu, $\mathrm{L}$. Wang, Costs and benefits of renewable energy development in China's power industry, „Renewable Energy" 2019, vol. 131, s. 700-712.

10 O tym szczegółowo: J. Lewis, R. Wiser, Fostering a renewable energy..., s. 1844-1857; Z. Zhao, W. Ling, G. Zillante, J. Zuo, Comparative Assessment of Performance of Foreign and Local Wind Turbine Manufacturers in China, „Renewable Energy” 2012, vol. 39, s. 424-432; S. Zhoua, Y. Wanga, Y. Zhoub, L. Clarke, J. Edmonds, Roles of wind and solar energy in China's power sector: Implications of intermittency constraints, „Applied Energy” 2018, vol. 213, s. 22-30.

11 Zob. np. GWEC (2019), Global Wind Report 2018; REN21, Renewables 2019. Global Status Report, Paris 2019; IRENA, Renewable Energy and Jobs. Annual Review 2019, Abu Dhabi 2019.

12 L. Gacek, Azja Centralna w polityce energetycznej Chin, Kraków 2013; idem, Zielona energia w Chinach. Zrównoważony rožwój, ochrona środowiska, gospodarka niskoemisyjna, Kraków 2015. 
zwiększył się z 1660 mld USD w 2003 r. do 13608 mld USD w 2018 r., a PKB per capita wzrósł z 1289 USD w 2003 r. do 9771 USD w 2018 r. ${ }^{13}$

Tak szybki i nieprzerwany wzrost gospodarczy nie byłby możliwy bez inwestowania w sektor energetyczny i zadbania o tzw. bezpieczeństwo energetyczne. Według Banku Światowego bezpieczeństwo energetyczne oznacza zapewnienie zrównoważonej produkcji i konsumpcji energii w rozsądnej cenie, w taki sposób, aby wzmacniać wzrost gospodarczy, redukować ubóstwo oraz bezpośrednio poprawiać jakość życia ludzi przez rozszerzenie dostępu do zaawansowanych usług energetycznych ${ }^{14}$.

Tabela 1. Tempo wzrostu gospodarczego na świecie, w Chinach, USA, Japonii i Niemczech

\begin{tabular}{|c|c|c|c|c|c|}
\hline Rok & Świat & Chiny & USA & Japonia & Niemcy \\
\hline 2003 & 2,9 & 10,0 & 2,9 & 1,5 & $-0,7$ \\
\hline 2004 & 4,4 & 10,1 & 3,8 & 2,2 & 1,2 \\
\hline 2005 & 3,9 & 11,4 & 3,5 & 1,7 & 0,7 \\
\hline 2006 & 4,3 & 12,7 & 2,9 & 1,4 & 3,7 \\
\hline 2007 & 4,2 & 14,2 & 1,9 & 1,7 & 3,3 \\
\hline 2008 & 1,9 & 9,7 & $-0,1$ & $-1,1$ & 1,1 \\
\hline 2009 & $-1,7$ & 9,4 & $-2,5$ & $-5,4$ & $-5,6$ \\
\hline 2010 & 4,3 & 10,6 & 2,6 & 4,2 & 4,1 \\
\hline 2011 & 3,1 & 9,6 & 1,6 & $-0,1$ & 3,7 \\
\hline 2012 & 2,5 & 7,9 & 2,2 & 1,5 & 0,5 \\
\hline 2013 & 2,7 & 7,8 & 1,8 & 2,0 & 0,5 \\
\hline 2014 & 2,8 & 7,3 & 2,5 & 0,4 & 2,2 \\
\hline 2015 & 2,9 & 6,9 & 2,9 & 1,2 & 1,7 \\
\hline 2016 & 2,6 & 6,7 & 1,6 & 0,6 & 2,2 \\
\hline 2017 & 3,2 & 6,8 & 2,2 & 1,9 & 2,2 \\
\hline 2018 & 3,0 & 6,6 & 2,9 & 0,8 & 1,4 \\
\hline $2003-2018$ & & & & & \\
(średnie & 2,9 & 9,2 & 2,0 & 0,9 & 1,4 \\
tempo & & & & & \\
\hline zzrostu) & & & & & \\
\hline
\end{tabular}

Źródło: World Bank (2019), https://data.worldbank.org/indicator/ny.gdp.mktp.kd.zg (dostęp: 19.08.2019).

13 data.worldbank.org/indicator/ny.gdp.mktp.cd (dostęp: 29.08.2019); data.worldbank.org/ indicator/ny.gdp.pcap.cd (dostęp: 29.08.2019).

14 World Bank, Energy Security Issues, The World Bank Group, Moscow-Washington DC 2005. 
Współczesna gospodarka zużywa duże ilości energii elektrycznej. Jeszcze w 2003 r. zdecydowanym liderem w produkcji energii elektrycznej byly Stany Zjednoczone. Produkcja ta, wynoszaca 4138 TWh, była ponad 2 razy większa niż w Chinach (1911 TWh). Jednak szybka rozbudowa mocy wytwórczych (opartych głównie na węglu) spowodowała, że Chiny w 2011 r. wyprzedziły USA, a w 2018 r. ich przewaga nad Stanami Zjednoczonymi wynosiła już $2651 \mathrm{TWh}^{15}$ (tab. 2).

Chiny nie posiadają wystarczających (z punktu widzenia potrzeb) zasobów ropy naftowej oraz gazu ziemnego, dlatego sektor energetyczny oparły na węglu (tab. 3), którego rozpoznane złoża są obfite - wynoszą około 138,8 mld ton (co stanowi $13,2 \%$ zasobów światowych $)^{16}$.

Tabela 2. Produkcja energii elektrycznej (w TWh)

\begin{tabular}{|c|c|c|c|c|c|c|}
\hline Rok & Świat & Japonia & Niemcy & USA & Chiny & $\begin{array}{c}\text { Udział Chin } \\
(\mathbf{w} \text { \%) }\end{array}$ \\
\hline 2003 & 16919 & 1093 & 609 & 4138 & 1911 & 11,3 \\
\hline 2004 & 17702 & 1121 & 617 & 4232 & 2203 & 12,4 \\
\hline 2005 & 18452 & 1153 & 623 & 4323 & 2500 & 13,6 \\
\hline 2006 & 19156 & 1164 & 640 & 4331 & 2866 & 15,0 \\
\hline 2007 & 20041 & 1180 & 641 & 4432 & 3282 & 16,4 \\
\hline 2008 & 20433 & 1184 & 641 & 4390 & 3496 & 17,1 \\
\hline 2009 & 20269 & 1114 & 596 & 4206 & 3715 & 18,3 \\
\hline 2010 & 21574 & 1156 & 633 & 4394 & 4207 & 19,5 \\
\hline 2011 & 22259 & 1104 & 613 & 4363 & 4713 & 21,2 \\
\hline 2012 & 22808 & 1107 & 630 & 4311 & 4988 & 21,9 \\
\hline 2013 & 23450 & 1088 & 639 & 4330 & 5432 & 23,2 \\
\hline 2014 & 23915 & 1063 & 628 & 4363 & 5650 & 23,6 \\
\hline 2015 & 24287 & 1030 & 648 & 4349 & 5815 & 23,9 \\
\hline 2016 & 24957 & 1042 & 651 & 4348 & 6133 & 24,6 \\
\hline 2017 & 25677 & 1050 & 654 & 4303 & 6604 & 25,7 \\
\hline 2018 & 26615 & 1052 & 649 & 4461 & 7112 & 26,7 \\
\hline
\end{tabular}

Źródło: BP Statistical Review of World Energy, June 2019, https://www.bp.com/en/global/corporate/energy-economics/statistical-review-of-world-energy.html (dostęp: 19.08.2019).

W latach 2003-2018 Chiny zwiększyły produkcję energii elektrycznej w elektrowniach węglowych ponad trzykrotnie - z 1520,0 TWh w 2003 r. do 4732,4 TWh w 2018 r., jednocześnie zwiększając swój udział w rynku światowym z 22,5\% do 46,9\% (tab. 3).

15 BP Statistical Review of World Energy, June 2019.

16 Ibidem. 
Tabela 3. Produkcja energii elektrycznej w elektrowniach węglowych (w TWh)

\begin{tabular}{|c|c|c|c|c|c|c|}
\hline Rok & Świat & Japonia & Niemcy & USA & Chiny & $\begin{array}{c}\text { Udział Chin } \\
\mathbf{( w} \text { \%) }\end{array}$ \\
\hline 2003 & 6762,2 & 288,0 & 304,6 & 2139,1 & 1520,0 & 22,5 \\
\hline 2004 & 6988,1 & 291,1 & 298,8 & 2143,6 & 1722,4 & 24,6 \\
\hline 2005 & 7360,4 & 315,1 & 288,1 & 2178,9 & 1980,1 & 26,9 \\
\hline 2006 & 7771,0 & 307,5 & 288,9 & 2155,6 & 2302,4 & 29,6 \\
\hline 2007 & 8261,6 & 313,0 & 297,1 & 2182,7 & 2656,7 & 32,2 \\
\hline 2008 & 8277,5 & 331,0 & 275,2 & 2147,9 & 2708,9 & 32,7 \\
\hline 2009 & 8129,8 & 309,6 & 253,4 & 1899,5 & 2911,5 & 35,8 \\
\hline 2010 & 8658,4 & 312,7 & 262,9 & 1998,5 & 3239,2 & 37,4 \\
\hline 2011 & 9100,4 & 281,6 & 262,5 & 1876,3 & 3695,4 & 40,6 \\
\hline 2012 & 9141,6 & 330,8 & 277,1 & 1640,8 & 3755,8 & 41,1 \\
\hline 2013 & 9597,1 & 359,2 & 288,2 & 1713,9 & 4074,2 & 42,5 \\
\hline 2014 & 9628,8 & 353,1 & 274,4 & 1713,7 & 4070,9 & 42,3 \\
\hline 2015 & 9412,0 & 346,7 & 272,2 & 1468,3 & 4042,5 & 43,0 \\
\hline 2016 & 9507,4 & 370,6 & 261,7 & 1346,2 & 4163,6 & 43,8 \\
\hline 2017 & 9806,2 & 361,8 & 241,9 & 1310,0 & 4445,5 & 45,3 \\
\hline 2018 & 10100,5 & 347,2 & 229,0 & 1245,8 & 4732,4 & 46,9 \\
\hline
\end{tabular}

Źródło: BP Statistical Review of World Energy, June 2019.

W tym samym okresie zarówno Amerykanie, jak i Niemcy bardzo mocno ograniczyli produkcję energii elektrycznej w elektrowniach węglowych. Inaczej wygląda sytuacja w Japonii, kraju bardzo ubogim w surowce energetyczne. Po katastrofie elektrowni jądrowej w Fukushimie Japonia zwiększyła skalę produkcji energii elektrycznej w elektrowniach węglowych.

$\mathrm{Na}$ tle analizowanych państw udział węgla w produkcji energii elektrycznej w Chinach jest bardzo wysoki, bo wynosi 66,5\%, podczas gdy w Niemczech 35,3\%, Japonii - 33,0\%, a w USA - 27,9\% ${ }^{17}$ (tab. 4).

Wysokie tempo wzrostu gospodarczego w latach 80. i 90. ubiegłego wieku przyczyniło się do zwiększenia dochodów oraz poprawy jakości życia mieszkańców Chin, ale wzrost ten został okupiony znacznym pogorszeniem stanu środowiska naturalnego. Szczególnie w dużych miastach zanieczyszczenie powietrza stało się bardzo dokuczliwe dla mieszkańców. Zdając sobie sprawę z konsekwencji dalszego zwiększania mocy wytwórczych w energetyce węglowej, chiński rząd opublikował w 1996 r. dokument pt. The Outline of New Energy and Renewable Energy Development in China of 2010, w którym nakreślono plan rozwoju energetyki

17 Ibidem. 
Tabela 4. Miks energetyczny - procent energii elektrycznej wytwarzanej z danego źródła w 2018 r.

\begin{tabular}{|l|r|r|r|r|r|}
\hline $\begin{array}{c}\text { Źródło } \\
\text { energii }\end{array}$ & Świat & Japonia & Niemcy & USA & Chiny \\
\hline Ropa & 3,0 & 5,7 & 0,8 & 0,6 & 0,2 \\
\hline Gaz & 23,2 & 36,8 & 12,8 & 35,4 & 3,1 \\
\hline Węgiel & 38,0 & 33,0 & 35,3 & 27,9 & 66,5 \\
\hline Jądrowe & 10,2 & 4,7 & 11,7 & 19,0 & 4,1 \\
\hline Wodne & 15,8 & 7,7 & 2,6 & 6,5 & 16,9 \\
\hline OZE & 9,3 & 10,7 & 32,2 & 10,3 & 8,9 \\
\hline Inne & 0,6 & 1,5 & 4,5 & 0,3 & 0,2 \\
\hline Razem & 100,0 & 100,0 & 100,0 & 100,0 & 100,0 \\
\hline
\end{tabular}

Źródło: BP Statistical Review of World Energy, June 2019.

bazującej na odnawialnych źródłach energii (OZE), w tym energetyki wiatrowej ${ }^{18}$. W najnowszym XIII planie pięcioletnim oraz w dokumencie pt. Energy Supply and Consumption Revolution Strategy (2016-2030) określono kierunki rozwoju energetyki w Chinach, w ramach których mają być zwiększane moce wytwórcze przede wszystkim w energetyce solarnej (głównie fotowoltaice), energetyce wiatrowej i hydroenergetyce ${ }^{19}$. Nie przewiduje się jeszcze odchodzenia od węgla, raczej wyhamowanie tempa rozwoju energetyki węglowej. Z konwencjonalnych źródeł energii na znaczeniu ma zyskiwać gaz, którego produkcję planuje się zwiększyć o $60 \%$ do $2020 \mathrm{r}$.

\section{Budowa innowacyjnego ekosystemu biznesowego w energetyce wiatrowej w Chinach}

Do powstania i rozwoju ekosystemu biznesowego potrzebne są odpowiednie środki finansowe, pochodzące od ostatecznych nabywców produktów i usług, banków, inwestorów, firm venture capital czy rządu. Energetyka wiatrowa w Chinach zaczęła się rozwijać dopiero w latach 90. ubiegłego wieku w oparciu o import technologii. Zakupiono licencje i patenty, ściąnięto światowych liderów. Jeszcze w 2005 r. udział w chińskim rynku czterech zagranicznych firm: Vestas, GE, Gamesa i Enercon

${ }_{18}$ G. Xinyua, J. Boc, L. Bina, Y. Kaia, Study on Renewable Energy Development and Policy in China, „Energy Procedia” 2011, vol. 5, s. 1284-1290.

19 China Investment Report, Energy Charter Secretariat, Brussels 2017. 
wynosił około 75\%, by w 2011 r. zmniejszyć się do 38\% $\%^{20}$. Ostatecznie zdecydowaną większość rynku przejęły rodzime firmy, zajmujące się produkcją i instalacja elektrowni wiatrowych.

Rząd chiński niejako wymusił na zagranicznych inwestorach transfer technologii. Chcąc sprzedawać elektrownie wiatrowe na rosnącym chińskim rynku, trzeba było część produkcji komponentów zlecać lokalnym producentom. W ten sposób firmy chińskie zdobywały know-how i stopniowo zwiększały swoje zdolności produkcyjne. Początkowo kupowały licencje i patenty, ale dzięki subsydiom rządowym przeznaczonym na badania i rozwój (R\&D) stopniowo wprowadzały własne, unikalne rozwiązania. W pierwszej fazie koncentrowały się na rynku krajowym - do 2009 r. chińskie firmy praktycznie nie zajmowały się eksportem turbin wiatrowych.

Pierwsze programy wsparcia energetyki wiatrowej w Chinach zastosowano już w latach 1998-2003. W 1999 r. rząd ustanowił fundusz o wartości 1 mld CNY przeznaczony dla małych i średnich firm technologicznych działających w energetyce bazującej na OZE ${ }^{21}$. Zaczęto też testować pierwsze taryfy gwarantowane (feed-in tariffs, FIT), czyli długotrwałe kontrakty, mające pokryć wszystkie koszty producenta energii pochodzącej z OZE i zapewnić mu satysfakcjonującą stopę zwrotu z inwestycji. Przed 2003 r. najniższe centralne taryfy wynosiły 0,38 CNY/kWh, a najwyższe ponad $1 \mathrm{CNY} / \mathrm{kWh}$. Taryfy (feed-in tariff) akceptowane przez władze prowincji wynosiły wtedy od około 0,20-0,40 CNY/kWh (co stanowiło ekwiwalent elektrowni węglowych) do ponad $1 \mathrm{CNY} / \mathrm{kWh}^{22}$. Po 2003 r. Narodowa Komisja Rozwoju i Reform Chińskiej Republiki Ludowej (National Development and Reform Commission - NDRC) zorganizowała kilka przetargów na koncesjonowane projekty. Uzyskane ceny były relatywnie niskie $0,38-0,50 \mathrm{CNY} / \mathrm{kWh}$, podczas gdy lokalne rządy akceptowały stawki nawet na poziomie 0,50-0,80 CNY/kWh. W 2005 r. wprowadzono przełomowa ustawę Renewable Energy Law of the People's Republic of China, stwarzająca ramy prawne dla rozwoju gospodarki niskoemisyjnej opartej na odnawialnych źródłach energii (OZE). W dokumencie tym wskazano m.in. na konieczność większego wykorzystania energii wiatru. W latach 2006-2009 w ramach programu Interim Measures on Renewable Energy Electricity Prices and Cost Sharing Management wprowadzono system licytacji. W 2008 r. poziom taryf zaakceptowanych przez NDRC mieścił się w granicach 0,51-0,61 CNY/kWh. Od 2009 r. w ramach programu Improving Policies on the Feed-in Tariff of Wind Power NDRC wprowadziła benchmarki dla taryf stosowanych w różnych regionach Chin - wynosiły one odpowiednio 0,51, 0,54, 0,58 i 0,61 CNY za 1 kWh. Uwzględniono w ten sposób zróżnicowane koszty budowy, funkcjonowania, przyłączenia do

${ }^{20}$ J. Streeter, D. Goldstein, Understanding China's renewable energy technology exports, „Energy Policy", January 2013, vol. 52, s. 417-428.

21 J. Cherni, J. Kentish, Renewable energy policy and electricity market reforms in China, „Energy Policy" 2007, vol. 35, issue 7, s. 3616-3629.

22 Z. Ming, L. Ximei, L. Na, X. Song, Overall review... 
sieci, a także różne wielkości produkcji energii elektrycznej (zależne od wskaźników wietrzności) w poszczególnych regionach ${ }^{23}$.

Do 2010 r. wydano w Chinach na energetykę wiatrową łącznie około 313 mld CNY. Do 2020 r. suma ta może wzrosnąć nawet do 1777 mld CNY. W dłuższej perspektywie - do 2030 r. skumulowane wydatki na energetykę wiatrową mogą wynieść 3834 mld CNY, a do 2050 r. nawet do 12096 mld CNY ${ }^{24}$.

Kolejny przełom w chińskiej polityce energetycznej nastapił wraz z uchwaleniem XII planu pięcioletniego (2011-2015). Zapisano w nim bardzo ambitne cele, w tym zwiększenie łącznej mocy elektrowni wiatrowych do poziomu $105 \mathrm{GW}^{25}$. W $2011 \mathrm{r}$. chińscy producenci dysponowali już na tyle zaawansowaną technologia w zakresie elektrowni wiatrowych, że rozpoczęli sprzedaż eksportowa, m.in. do Brazylii i RPA (Sinovel), USA (United Power, Sany Electric i Chongqing Haizhuang), Indii (Shanghai Electric), a największa chińska firma Goldwind uzyskała zamówienia pochodzące m.in. z USA, Australii, Chile, Ekwadoru i Etiopii ${ }^{26}$.

Godnym uwagi przykładem jest tutaj firma Goldwing, obecnie jeden ze światowych liderów, jeśli chodzi o sprzedaż turbin wiatrowych. Przedsiębiorstwo to zaczynało od produkcji małych turbin wiatrowych na licencji kupionej od niemieckiej firmy REpower. Większe turbiny zaczęto produkować wspólnie z inną niemiecką firmą Vensys, którą ostatecznie w 2008 r. Goldwing przejął ${ }^{27}$.

W 2016 r. Chiny ogłosiły XIII plan pięcioletni (2016-2020), w ramach którego zdefiniowano jeszcze wyższe cele w zakresie energetyki wiatrowej. Łączna moc zainstalowanych turbin wiatrowych ma się zwiększyć ze 129 GW w 2015 r. do 210 GW w 2020 r. $^{28}$

Według danych pochodzących z najnowszego opracowania REN21: Renewables 2019 Global Status Report w okresie 2008-2018 Chiny wydały łącznie na instalacje związane z wykorzystaniem OZE ponad 823 mld USD. Udział Chin w światowych wydatkach na tego typu technologie wyniósł w 2017 r. aż 44,7\%, by w 2018 r. zmniejszyć się do $31,6 \%$.

Przy zaangażowaniu odpowiednich publicznych środków można stworzyć ekosystem biznesowy, w którym powstaną inwestycje w OZE, ale w wielu krajach (np. w Polsce) firmy działające w ramach tych ekosystemów są nastawione głównie na przejęcie środków (value capture) pochodzących z rządowych programów wsparcia energetyki wiatrowej, a nie na wprowadzanie innowacji (value creation). W państwach tych kluczowe technologie i urządzenia (m.in. turbiny i przekładnie)

23 Ibidem.

24 J. Streeter, D. Goldstein, Understanding China's..., s. 417-428.

25 iea.org/policiesandmeasures/pams/china/ (dostęp: 23.08.2019).

26 Ibidem.

27 J. Streeter, D. Goldstein, Understanding China's..., s. 417-428.

28 China Investment Report...

29 REN21, Renewables 2019... 
są importowane, nie ma rozwiniętej działalności naukowo-badawczej oraz patentowania nowych rozwiązań technologicznych.

Inaczej wygląda sytuacja w Chinach. W 2010 r. Ministerstwo Nauki i Technologii oraz National Energy Bureau wspólnie sfinansowały powstanie wielu centrów R\&D i laboratoriów dla energetyki wiatrowej, których zadaniem było prowadzenie badań i testowanie nowych rozwiązań technologicznych. W 2011 r. powstał ośrodek badawczy National Energy Key Laboratory for Wind Energy \& Solar Energy Emulation and Inspection Certification Technology, stanowiący platformę badawczo-usługową i certyfikującą dla energetyki wiatrowej i solarnej. Zbudowano też wiele projektów demonstracyjnych, na których testowano nowe technologie. Dzięki inwestycjom w R\&D Chiny szybko osiagnęły zdolność samodzielnego wytwarzania wszystkich kluczowych elementów elektrowni wiatrowych.

Wydatki na R\&D w energetyce wiatrowej przeznaczane są głównie na opracowanie nowych, większych turbin. Chiny mają obecnie dziesięć głównych producentów turbin, którzy dostarczają urządzenia o mocy najczęściej od 2,5 MW do 3,6 MW. Istnieja już jednak prototypy turbin o mocy $5 \mathrm{MW}$, a trwają badania nad turbinami o mocy $10 \mathrm{MW}$, które miałyby zostać zainstalowane na morzu ${ }^{30}$.

\section{Funkcjonowanie ekosystemu biznesowego} w energetyce wiatrowej w Chinach w latach 2003-2018

W Chinach panują bardzo sprzyjające warunki do rozwoju energetyki wiatrowej. Całkowite możliwości produkcji energii w turbinach wiatrowych szacuje się na 2-3,4 TW na lądzie i 0,5 TW na morzu ${ }^{31}$.

Po uchwaleniu XI planu pięcioletniego (2006-2010) zaczęto przeznaczać w Chinach coraz większe kwoty na rozwój energetyki wiatrowej. Przez 3 kolejne lata moc elektrowni wiatrowych zwiększała się o około $100 \%$ w skali roku, natomiast w 2010 r. o 68\%, dzięki czemu już w 2011 r. Chiny zajęły pozycję światowego lidera (tab. 5). W 2018 r. ChRL udało się zwiększyć przewagę nad Stanami Zjednoczonymi do ponad 90 GW. Udział Chin w rynku światowym osiagnął wtedy 32,7\%. Zgodnie z XII planem pięcioletnim (2011-2015) do 2015 r. moc zainstalowanych turbin wiatrowych miała sięgnać $100 \mathrm{GW}^{32}$, w rzeczywistości przekroczyła $131 \mathrm{GW}^{33}$.

30 IEA, China Wind Energy Development Roadmap 2050, IEA Technology Roadmaps, OECD Publishing, Paris 2012, https://doi.org/10.1787/9789264166752-en (dostęp: 20.11.2019).

31 BP Statistical Review of World Energy, June 2019.

32 Z. Ming, L. Ximei, L. Na, X. Song, Overall review..., s. 260-271.

33 J. Streeter, D. Goldstein, Understanding China's..., s. 417-428. 
Ostatni XIII plan pięcioletni zakłada, że moc elektrowni wiatrowych włączonych do sieci w 2020 r. wyniesie minimum 210 GW. Cel prawdopodobnie zostanie osiagnięty bez większych problemów, bo już w 2018 r. łączna moc turbin wiatrowych podłączonych do sieci wynosiła prawie 185 GW (tab. 5). Przez wiele lat Chiny pozostawały w tyle, jeśli chodzi o turbiny wiatrowe stosowane na morzu (offshore wind projects). Jednak w 2018 r. dzięki inwestycjom sięgającym 11,4 mld USD wysunęły się na pierwsze miejsce na świecie.

W przypadku energetyki wiatrowej ChRL koncentruje się na razie na swoim rodzimym rynku. Liderem w transakcjach międzynarodowych jest Dania (42\%), która wyprzedza Niemcy (29\%) i Hiszpanię (15\%). Chiny z 8\% udziałem zajmuja dopiero 4. miejsce ${ }^{34}$.

Tabela 5. Moc zainstalowanych turbin wiatrowych (w MW)

\begin{tabular}{|c|r|r|r|r|r|c|}
\hline Rok & Świat & Japonia & Niemcy & USA & Chiny & $\begin{array}{c}\text { Udział Chin } \\
(\mathbf{w} \% \mathbf{~}\end{array}$ \\
\hline 2003 & 38392 & 508 & 14381 & 5995 & 547 & 1,4 \\
\hline 2004 & 46917 & 769 & 16419 & 6456 & 763 & 1,6 \\
\hline 2005 & 58452 & 1227 & 18248 & 8706 & 1060 & 1,8 \\
\hline 2006 & 73166 & 1805 & 20474 & 11329 & 2070 & 2,8 \\
\hline 2007 & 91511 & 1527 & 22116 & 16515 & 4200 & 4,6 \\
\hline 2008 & 115363 & 1756 & 22794 & 24651 & 8388 & 7,3 \\
\hline 2009 & 150181 & 1997 & 25732 & 34296 & 17599 & 11,7 \\
\hline 2010 & 180941 & 2294 & 26903 & 39135 & 29634 & 16,4 \\
\hline 2011 & 220129 & 2419 & 28712 & 45676 & 46355 & 21,1 \\
\hline 2012 & 267113 & 2562 & 30979 & 59075 & 61597 & 23,1 \\
\hline 2013 & 300303 & 2645 & 33477 & 59973 & 76731 & 25,6 \\
\hline 2014 & 349699 & 2753 & 38614 & 64232 & 96819 & 27,7 \\
\hline 2015 & 416739 & 2808 & 44580 & 72573 & 131048 & 31,4 \\
\hline 2016 & 467578 & 3246 & 49592 & 81386 & 148517 & 31,8 \\
\hline 2017 & 515175 & 3392 & 55718 & 87543 & 164392 & 31,9 \\
\hline 2018 & 564347 & 3653 & 59420 & 94295 & 184696 & 32,7 \\
\hline
\end{tabular}

Źródło: BP Statistical Review of World Energy, June 2019.

Sam fakt zbudowania elektrowni wiatrowych o największej na świecie łącznej mocy nie od razu przełożył się na pozycję lidera w produkcji energii elektrycznej w turbinach wiatrowych. Chiny przez pewien czas miały problemy z przyłączaniem nowych elektrowni wiatrowych do sieci energetycznej. Zgodnie z XII planem

34 IRENA, Renewable Energy and Jobs. Annual Review 2018, Abu Dhabi 2018. 
pięcioletnim do 2015 r. produkcja energii elektrycznej w elektrowniach wiatrowych miała sięgnąć $190 \mathrm{TWh}^{35}$, w rzeczywistości była nieznacznie mniejsza i wyniosła 185,8 TWh.

Dwóm kontrolowanym przez państwo operatorom sieci State Power Grid i South Power Grid początkowo brakowało bodźców do podłączania nowych dostawców energii bazujących na OZE. Udział farm wiatrowych w ogólnej produkcji energii elektrycznej był bardzo mały, a koszty przyłączenia do sieci oraz jej rozbudowy bardzo duże. Dlatego też pojawily się problemy, w tym sytuacje, kiedy to gotowe elektrownie wiatrowe nie miały dostępu do siecisi. Jednak już w 2016 r. wielkość produkcji energii elektrycznej w chińskich elektrowniach wiatrowych okazała się największa na świecie i wyniosła 237,1 TWh. W 2018 r. wielkość produkcji energii elektrycznej w elektrowniach wiatrowych w Chinach wzrosła do 366 TWh, co stanowiło $28,8 \%$ produkcji światowe ${ }^{37}$ (tab. 6).

Tabela 6. Produkcja energii elektrycznej w zainstalowanych turbinach wiatrowych (w TWh)

\begin{tabular}{|c|r|r|r|r|r|c|}
\hline Rok & Świat & Japonia & Niemcy & USA & Chiny & $\begin{array}{c}\text { Udział Chin } \\
\text { (w } \% \mathbf{~}\end{array}$ \\
\hline 2003 & 62,9 & 0,8 & 18,7 & 11,3 & 1,0 & 1,6 \\
\hline 2004 & 85,1 & 1,4 & 25,5 & 14,3 & 1,3 & 1,5 \\
\hline 2005 & 104,1 & 1,9 & 27,2 & 18,0 & 1,9 & 1,9 \\
\hline 2006 & 132,9 & 2,1 & 30,7 & 26,9 & 3,7 & 2,8 \\
\hline 2007 & 170,7 & 2,7 & 39,7 & 34,8 & 5,5 & 3,2 \\
\hline 2008 & 220,6 & 2,9 & 40,6 & 55,9 & 13,1 & 5,9 \\
\hline 2009 & 275,9 & 3,4 & 38,6 & 74,6 & 27,6 & 10,0 \\
\hline 2010 & 341,6 & 3,9 & 38,5 & 95,6 & 44,6 & 13,1 \\
\hline 2011 & 436,8 & 4,5 & 49,9 & 121,4 & 70,3 & 16,1 \\
\hline 2012 & 523,8 & 4,7 & 51,7 & 142,2 & 96,0 & 18,3 \\
\hline 2013 & 645,3 & 5,1 & 52,7 & 169,5 & 141,2 & 21,9 \\
\hline 2014 & 712,0 & 5,0 & 58,5 & 183,5 & 156,1 & 21,9 \\
\hline 2015 & 831,4 & 5,2 & 80,6 & 192,6 & 185,8 & 22,3 \\
\hline 2016 & 956,9 & 5,3 & 79,9 & 229,3 & 237,1 & 24,8 \\
\hline 2017 & 1128,0 & 6,1 & 105,7 & 256,9 & 295,0 & 26,2 \\
\hline 2018 & 1270,0 & 6,8 & 111,6 & 277,7 & 366,0 & 28,8 \\
\hline
\end{tabular}

Źródło: BP Statistical Review of World Energy, June 2019.

35 Z. Ming, L. Ximei, L. Na, X. Song, Overall review..., s. 260-271.

36 F. Wang, H. Yin, S. Li, China's renewable energy policy..., s. 1872-1878.

37 BP Statistical Review of World Energy, June 2019. 
Według Global Wind Energy Council (GWEC) ${ }^{38}$ w 2018 r. zainstalowano na świecie 20641 turbin wiatrowych o łącznej mocy 50,6 GW. W pierwszej dziesiątce największych producentów znalazło się pięć firm z Chin: Goldwind, Envision Energy, Mingyang, Guodian United Power i Sewind (tab. 7).

Warto wspomnieć, że jedną z kluczowych grup interesariuszy w energetyce są pracownicy firm produkujących, instalujących i serwisujacych turbiny wiatrowe. W latach 2009-2010 w Chinach przybywało około 15 miejsc pracy na $1 \mathrm{MW}$ zainstalowanej mocy w elektrowniach wiatrowych. Energetyka wiatrowa zapewnia na świecie około 1,16 mln miejsc pracy, z czego 44\% przypada na Chiny, gdzie w branży tej pracuje około 510 tys. osób ${ }^{39}$. W UE takich miejsc pracy jest około 314 tys., a w USA 114 tys. ${ }^{40}$ Przyjmuje się, że wraz z rozwojem technologii (instalowaniem turbin o coraz większej mocy) wskaźnik ten ma zmniejszyć się do 13 w 2020 r., 12 w 2030 r. i 10 w 2050 r. ${ }^{41}$ Miejsca pracy w energetyce wiatrowej są bardzo cenione, bo oferują znacznie wyższe płace, niż wynosi średnia dla całej gospodarki.

Tabela 7. Dziesięciu największych producentów turbin wiatrowych na świecie (w GW)

\begin{tabular}{|l|c|c|}
\hline \multicolumn{1}{|c|}{ Producent } & $\begin{array}{c}\text { Moc turbin wiatrowych } \\
\text { (w GW) }\end{array}$ & $\begin{array}{c}\text { Udział w rynku } \\
\text { (w } \mathbf{~} \mathbf{\text { }}\end{array}$ \\
\hline Vestas (Dania) & 10,3 & 20,3 \\
\hline Goldwind (Chiny) & 7,0 & 13,8 \\
\hline Siemens Gamesa (Niemcy/Hiszpania) & 6,2 & 12,3 \\
\hline GE Renewable (USA) & 5,1 & 10,0 \\
\hline Envision Energy (Chiny) & 4,3 & 8,4 \\
\hline Enercon (Niemcy) & 2,8 & 5,5 \\
\hline Mingyang (Chiny) & 2,6 & 5,2 \\
\hline Nordex Acciona (Niemcy) & 2,5 & 5,0 \\
\hline Guodian United Power (Chiny) & 1,3 & 2,5 \\
\hline Sewind (Chiny) & 1,2 & 2,3 \\
\hline
\end{tabular}

Źródło: REN21, Renewables 2019. Global Status Report, Paris 2019.

38 GWEC (2019), Global Wind Report 2018.

39 IRENA, Renewable Energy and Jobs. Annual Review 2019, Abu Dhabi 2019.

40 Ibidem.

41 IEA, China Wind Energy Development Roadmap 2050... 


\section{Podsumowanie}

W relatywnie krótkim okresie Chiny przeszły drogę od kraju stawiającego pierwsze kroki w energetyce wiatrowej do pozycji światowego lidera w tej dziedzinie. Na podstawie studiów literaturowych oraz analizy danych statystycznych można określić kluczowe determinanty sukcesu chińskiej polityki energetycznej.

Po pierwsze, Chiny postawiły energetykę, a w szczególności jej część bazująca na OZE, na wysokim miejscu na liście priorytetów pięcioletnich planów społeczno-gospodarczych. Ochrona środowiska stała się jednym z kluczowych celów polityki gospodarczej.

Po drugie, Chiny zbudowały cały ekosystem biznesowy w energetyce wiatrowej, obejmujący nie tylko producentów i użytkowników technologii, ale także ośrodki naukowe i instytucje finansowe. Jeszcze kilkanaście lat temu chińskie firmy importowały kluczowe elementy technologii w energetyce wiatrowej, a w tej chwili obsługują cały łańcuch wartości. Zaprezentowane dane potwierdzają hipotezę pierwsza, sugerująca, że osiagnięcie tak wielkiej skali produkcji oraz wysokiego tempa rozwoju energetyki wiatrowej w Chinach wymagało zbudowania całego ekosystemu biznesowego.

Chiny wypracowały najpierw silny popyt na projekty wiatrowe, przyciagając tym samym wiodących zagranicznych producentów. Za pomocą odpowiednich regulacji oraz bezpośredniego wsparcia rodzimych producentów doprowadzono do transferu technologii, stworzenia dużych krajowych zdolności wytwórczych oraz własnego know-bow. Chińskie firmy stopniowo zaczęły przejmować rodzimy rynek instalacji wiatrowych, a następnie, posiadając już odpowiednie doświadczenie i zaawansowane technologie, a także przewagę kosztowa, zaczęły eksportować elektrownie wiatrowe nie tylko do krajów sąsiednich, ale nawet do tych wysoko rozwiniętych.

Wiele państw importuje tylko nowe technologie z zakresu energetyki wiatrowej (w szczególności turbiny wiatrowe, których udział w łącznych kosztach inwestycyjnych sięga nawet $60-70 \%$ ) i nie rozwija krajowych mocy wytwórczych oraz nie prowadzi prac badawczo-rozwojowych w tej dziedzinie. Kraje te w teście zaangażowania kapitału krajowego w procesy wytwórcze w nowej branży otrzymałyby niską ocenę. Inaczej wygląda sytuacja w przypadku Chin. Od samego początku wymagano od podmiotów zagranicznych (w tym czasie światowych liderów w dziedzinie energetyki wiatrowej) tworzenia joint venture z podmiotami krajowymi oraz angażowania krajowych kooperantów do kluczowych procesów wytwórczych. Po kilku latach krajowe podmioty były w stanie produkować większość podzespołów elektrowni wiatrowych. Przy wsparciu przez rząd procesów badawczo-rozwojowych firmy chińskie ostatecznie uzyskały zdolność wytwarzania kompletnych zestawów elektrowni wiatrowych. Po przetestowaniu ich na rynku krajowym rozpoczęto eksport na rynki zagraniczne, w tym na te najbardziej wymagające, czyli na rynek amerykański i rynek 
UE. W światowej czołówce producentów turbin wiatrowych znajdują się obecnie następujące chińskie firmy: Goldwind, Guodian United Power, Envision i Mingyang. W teście zaangażowania kapitału narodowego należy przyznać Chinom ocenę wysoką (najwyższą w trzystopniowej skali).

Po trzecie, Chiny przeznaczyły ogromne kwoty na rozwój energetyki wiatrowej. Pieniądze poszły nie tylko na zwiększenie mocy zainstalowanych urządzeń, ale także na badania i rozwój, co zapewniło Chińczykom przewagę technologiczną i kosztową nad kluczowymi konkurentami. Potwierdzenie w danych znalazła więc druga hipoteza, mówiąca, że rozwój energetyki wiatrowej w ChRL nie byłby możliwy bez zapewnienia odpowiedniego strumienia finansowania.

Po czwarte, w Chinach dzięki dofinansowaniu uniwersytetów, politechnik i instytutów naukowych, a także budowie nowych ośrodków naukowo-badawczych i laboratoriów stworzono chroniona patentami unikalną technologię. Chiny z kraju, który jeszcze 20 lat temu stawiał pierwsze kroki w energetyce wiatrowej, stały się jednym z liderów w dziedzinie innowacji oraz posiadaczem największej liczby patentów w zakresie czystych technologii. Krytyczne znaczenie miały wydatki na R\&D. Innowacje przyczyniły się do budowy coraz większych turbin wiatrowych, o niższych kosztach operacyjnych. Połączenie wydatków państwa z wydatkami przedsiębiorstw (często również kontrolowanych przez państwo) w zakresie R\&D, w odpowiednim otoczeniu regulacyjnym, doprowadziło do tego, że chiński ekosystem energetyki wiatrowej jest nastawiony przede wszystkim na tworzenie wartości (value creation) w ramach działalności innowacyjnej, a nie tylko na przechwytywanie wartości (value capture), związane z programami finansowymi. Prezentowane dane potwierdzają więc hipotezę trzecią.

W przypadku Chin ocena innowacyjności ekosystemu biznesowego w energetyce wiatrowej musi być wysoka, bo po okresie uczenia się i wprowadzania innowacji miękkich, zwiększania wydatków na R\&D nastąpił czas wprowadzania innowacji twardych - chronionych patentami własnych technologii, które są eksportowane na rynki zagraniczne. Właścicielami patentów są zarówno chińskie uniwersytety i politechniki, jak i przedsiębiorstwa, takie jak chociażby: Sinovel, Shanghai Electric, Dongfang Electric, XEMC, CSIC Haizhuang i Zhejiang Windy.

Po 20 latach od rozpoczęcia budowy ekosystemu biznesowego w energetyce wiatrowej łączna moc zainstalowanych w Chinach elektrowni wiatrowych (185 GW) jest zdecydowanie największa na świecie, podobnie wygląda sytuacja z produkcją energii elektrycznej w tego typu instalacjach. To w Chinach w ostatnich latach instaluje się też najwięcej nowych elektrowni wiatrowych. Chińskie firmy zajmują czołowe miejsca w rankingach producentów turbin wiatrowych. W ChRL stworzono najwięcej, bo 0,5 mln miejsc pracy w energetyce wiatrowej.

Oczywiście nie wszystko, co działo się w chińskiej energetyce wiatrowej, odbywało się bez przeszkód i nieprzewidzianych kosztów. Okazało się m.in., że chińska sieć energetyczna nie jest dostosowana do tak gwałtownego przyrostu przyłączanych 
nowych mocy, pochodzących ze stosunkowo niestabilnych źródeł (wiatr). Część elektrowni wiatrowych nie była przyłączana w odpowiednim momencie do sieci, co powodowało straty potencjalnej energii oraz środków finansowych. Wolniej niż się spodziewano i określono w planach pięcioletnich rozwijała się energetyka wiatrowa na morzu (offshore). Dopiero w 2018 r. nastąpił gwałtowny przyrost zainstalowanych mocy.

Pomimo wspomnianych przeszkód i przejściowych problemów można mówić o niewątpliwym sukcesie chińskich programów rozwoju energetyki wiatrowej. Chińska inżynieria budowy ekosystemów biznesowych w energetyce wiatrowej może być punktem odniesienia lub wzorcem dla innych państw, w tym dla Polski, która swoja energetykę, podobnie jak niegdyś Chiny, wciąż opiera na węglu.

\section{SUMMARY}

\section{THE DEVELOPMENT OF WIND ENERGY IN CHINA}

Over the past 20 years, China has gone from being a country taking its first steps in wind energy to the position of a global leader in the field. The purpose of this article is to describe the factors that have determined the success of China's renewable energy policy. The descriptive method, comparative analysis, and a case study were used to verify hypotheses. The results of the analysis showed that the success of China's policy in the wind-energy sector was determined by such factors as prioritizing renewable energy in economic policy, setting specific goals for this policy, building entire business ecosystems in wind energy, ensuring a wide stream of financing, and constant introduction of innovations thanks to investments in $\mathrm{R} \& \mathrm{D}$ and human capital. 